\title{
Culture in Critical and Sociological Thought
}

\section{Mardian Political Economy}

Marx was a contemporary of Mill, but it is not clear that the latter had ever heard of the former or read his work (Hunt 2002, p. 204). Marx, on the other hand, thought of himself as a rival of Mill in that he was offering a radical revision of classical political economy to counterpoise Mill's bourgeois liberalism (Deane 1978). The men did have much in common intellectually, however. From classical political economy, both Marx and Mill imported the labour theory of value, belief in the falling rate of profit in capitalist industry, ideas about technologically induced unemployment, and the tendency to begin the analysis of economy with the assumption of three groups: landlords, capitalists (bourgeoisie), and labourers (proletariat). Marx, like all the classical political economists, was a holistic social scientist of the economy, as explained by Deane (1978),

The salient characteristic that Marx shared with Adam Smith, Jeremy Bentham, and JS Mill and which distinguished him from Ricardo ... was that he was a philosopher first and an economist second-a social scientist rather than a 'pure' economist. For Marx, political economy was merely one branch ... in the study of human social behaviour. (p. 126)

Perhaps, then, it is more useful to note the strong division between Marx and the neoclassical economists that would appear after his death, than to overly emphasize a schism between him and the classical political 
economists. The ahistorical, reductionist, methodological individualism of the neoclassical economists seems much more at odds with Marxian method than is the historically, politically, and ethically infused method of the political economists.

Despite his aversion to Ricardian economic reductionism, the theoretical cornerstone of Marx's work - the labour theory of value-was imported from Ricardo. He then mixed this theory of value with the Hegelian concept that history is propelled by conflict. The result was a materialist concept of history. Whereas Hegel's dialectic posited that social change stemmed from a conflict over ideas as the world was apprehended in different ways, Marx created a dialectic method that assumed the oppositethat history is driven by inherent conflict within the mode of material production, and that ideas emerge essentially as reflections of this material arrangement.

For Marx, "development" in Europe had been a process of historical change that was rooted in the social mode of production. In The German Ideology (2001), he argued that history passed through a number of phases. The first was a tribal phase-where production and consumption were based on kinship relationships and "the natural division of labour existing in the family" (p. 44). Population growth, however, intensified the aggregate "growth of wants," providing an impulse for increased trade and the establishment of a system of slavery (p. 44). Complexity, class divisions, conquest, slavery, and serfdom were intensified as European societies passed through periods of "primitive communism" and feudalism (pp. 44-46). The seeds for the transition to capitalism were planted in the feudal period - and this transition was largely made possible by the exploitation of colonial territories and the people that inhabited them. As Marx expressed in Das Kapital:

The discovery of gold and silver in America, the extirpation, enslavement and entombment in mines of the aboriginal population, the beginning of the conquest and looting of the East Indies, the turning of Africa into a warren for the commercial hunting of black-skins, signalled the rosy dawn of the era of capitalist production. (Marx 1867/1961, p. 751)

The bulk of the wealth expropriated through colonization was amassed by a merchant class. This process of amassing private wealth, along with the creation of a class of landless labourers, was called by Marx, the process of "primitive accumulation" (Marx 1867/1961, Part VIII). The warlike 
feudal aristocracy became increasingly indebted to the merchant class, and, as a result, the latter experienced increased political power. This, according to Marx, culminated in multiple revolutions that sought to replace the feudal system with one based on private property during the seventeenth and eighteenth centuries. The resultant privatization of feudal lands required the displacement of serfs who had no means left for survival beyond the sale of their own labour power-serfs, then, were transformed into a class of landless labourers:

The spoliation of the Church's property, the fraudulent alienation of the state domains, the robbery of common lands, the usurpation of feudal and clan property, and its transformation into private property under the circumstance of reckless terrorism, were just so many idyllic methods of primitive accumulation. They conquered the field for capitalist agriculture, made the soil part and parcel of capital, and created for the town industries the necessary supply of a "free" ... proletariat. (Marx 1867/1961, pp. 732-733)

For Marx, the existence of this landless labour force, the sanctification of private property, the accumulation of wealth from colonial pillage, and the productive technological innovations of the industrial revolution were the necessary preconditions for the existence of a capitalist society. Due largely to his adoption of the labour theory of value, however, Marx predicted that this system would end in a culmination of repeated crises that were rooted in its own internal contradictions. The culmination of these crises would see the marginalized, impoverished, and numerous proletariat expropriate capitalist industry, thus ushering in an era of socialism which would eventually transform itself into communism (Marx 1867/1961, Part VIII).

Starkly brandishing the enlightenment positivism that he, along with his contemporaries, was immersed in, Marx explained of his major contribution, Das Kapital, "it is the ultimate aim of this work to lay bare the economic law of motion of modern society" (p. 10). This method is evident in the teleology presented earlier. Marx's positivism did not, however, begin with an unqualified assumption about human nature similar to that which is embodied in homo economicus. Quite the reverse, he assumed that human activity was conditioned extensively by the material environment in which he existed, and that this material environment resulted from the technological method with which society produced the goods that it consumed. Deane (1978) explains regarding the seeming 
veracious greed of the capitalist; in the Marxian model, "accumulation is stimulated not by an innate psychological propensity on part of entrepreneurs, but by the social pressures of competitive society" (139). As Marx argued, the capitalist "shares with the miser the passion for wealth. But that which in the miser is a mere idiosyncrasy, is in the capitalist the effect of the social mechanism of which he is but one of the wheels" (1867/1961, pp. 236). Furthermore, regarding both the working class and the capitalist class, Marx and Engels assert in The Communist Manifesto (1848/1965) that the capitalist system made possible,

no other nexus between man and man than naked self-interest, than callous "cash payment." It has drowned the most heavenly ecstasies of religious fervour, of chivalrous enthusiasm, of philistine sentimentalism, in the icy water of egotistical calculation. (p. 15)

For Marx, then, self-interested behaviour was a cultural expression of capitalist relations of production.

Culture entered Marx's theory in two additional but interrelated ways - through the concept of ideology and the concept of fetishism. For Marx (1846/1968), ideology represented,

ideas which increasingly take on the form of universality. For each new class which puts itself on the place of the ruling class before it is compelled, merely in order to carry through its aim, to present its interest as the common interest of all the members of society, that is, expressed in ideal form: it has to give its ideas the form of universality, and present them as the only rational, universally valid ones. (chpt $1 \mathrm{~A}$, para. 21 )

Which ideas would become dominant in such a way depended entirely on the social structure of production in a given society. Since, "the class which has the means of mental production at its disposal, consequently also controls the means of mental production," it follows that "the ideas of the ruling class are in every epoch the ruling ideas" (ibid., para. 1). In such a way, Marx argued, the sanctity of private property, and liberal values in general, became part of the "hegemony of the spirit" that existed in capitalist society. These ideas were naturalized-rendered unquestionableeven though they so obviously (for Marx) benefitted only one class at the expense of another (ibid., para. 25). Ideology, then, was an image of society that was produced by the powerful and internalized by all (except for 
critical thinkers such as Marx himself apparently). It presented a mythical conception of reality that obscured to the proletariat the true nature of the exploitation that it was suffering, and called upon the working class to act voluntarily in the interest of the bourgeoisie and therefore against its own interest. Escape from this mystical snare was not possible through thought, due to Marx's assumption that it was the economic base that dictated through itself. The end of this delusion would be assured, however, as the contradiction in the material relations of production yielded the system's inevitable collapse (Marx 1867/1961).

Marx's concept of fetishism is also important if we are to explore the nature of culture in development theory. The period of high capitalist development that is to precede socialism, as we have noted, is typified in Marxian thought by an unprecedented capacity for the industrial production of commodities. These commodities, however, take on a mystical form, according to Marx, when they enter the sphere of exchange. Regarding the commodity:

So far as it is a value in use, there is nothing mysterious about it ... It is clear as noon-day that, that man, by his industry, changes the forms of the materials furnished by nature, in such a way as to make them useful to him ... But, so soon as it steps forth as a commodity, it is changed into something transcendent. It no longer stands with its feet on the ground, but, in relation to all other commodities. (Qtd in Heilbroner 1999, p. 165)

Upon encountering a commodity, a consumer is estranged from any knowledge of the nature of its production, and importantly, from the labour involved in its creation. Since Marx assumes all use value to be the measure of the labour used up in a commodity's production, it follows that the consumer has no means with which to judge the true value of the good. The commodity, then, has no obvious relation to the materiality of its production and becomes suspended in a relative system in which its value becomes arbitrarily designated. The exchange value which emerges is a "fetish" - a phantasm that is disconnected from the tangible reality of use value. Furthermore, since humans in a capitalist society come to relate to one another more and more solely through the purchase of commodities, they increasingly live life in relation to the sphere of exchange, with little understanding of the realm of production. As a result, they come to see their existence falsely as a competition with others for a limited supply of goods (Marx 1867/1961, Chpt. 1, Sct. 4). 
To summarize Marx's ideas as they relate to our present topic, he sees development as a unidirectional ascent from tribal society through feudal and capitalist epochs, finally to socialism and then to communism. All this movement is propelled by contradiction inherent in each stage. This transition is typified, at least until the socialist period, with the expansion of industrial output, but the change to capitalism that made this possible in Europe was predicated on the exploitation of colonized territories and peoples. Culture appears in Marx's thought as a form of "false consciousness," to use Engels' term (qtd in Eagleton 1991, p. 89). It is a naturalized worldview that supports the maintenance of a system of exploitation, it is a natural-seeming selfish form of action that is in fact the result of the conditioning of a system of production, and finally it is an imaginary relation to commodities which serves to obscure their true values of commodities. Culture, in Marx's thought, appears to us either as a mere reflection of an underlying power relation which compels humans to act against their own interests, or as a fanciful cloak which obscures from us a view of the hard reality of material production.

\section{Marxian Theories of Imperialism}

In The Communist Manifesto, Gundrisse, and Capital, Marx noted the tendency for capitalist nations to expand colonial territories in search of cheaper resources and to relieve negative pressures related to overproduction of commodities, through the establishment of new markets. This thesis was expanded upon later by Marxist scholars - most notably Hobson, Luxemburg, and Lenin. Marx had described the vital role that early colonialism played in providing the means of "primitive accumulation" that made European capitalism possible in the sixteenth, seventeenth, and early 8eighteenth centuries. Hunt (2002) explains, however, that this period was followed with a cooling of the drive to conquest as capitalist systems became entrenched and increasingly concentrated in the colonial centres themselves. In the final third of the nineteenth century, however, all of that changed as Great Britain, France, Germany, Belgium, Russia, Italy, and the United States embarked on intense and violent colonial expansion throughout Africa and Asia, and the Americas.

It was within this context that perhaps the three most notable Marxian thinkers of the late nineteenth and early twentieth century published their work on imperialism. The theories of Hobson, Luxemburg, and Lenin are 
remarkably similar in most respects. ${ }^{1}$ All claimed that the pressure for colonial expansion was a symptom of the contradictions inherent in the capitalism system. Hobson (1965), like Keynes, argued that the extreme concentration of wealth that had occurred in capitalist Europe and North America created an unstable economic situation. He argued that poor workers did not have enough wealth to purchase the commodities that were produced, and, since the wealthy could not possibly spend all of their huge earnings, there was at once a glut of consumer goods on European markets and excess capital available for investment. Hobson argued that this pressure led directly to colonialism:

Everywhere appear excessive powers of production, excessive capital in search of investment. It is admitted by all businessmen that growth of the powers of production in their country exceeds the growth in consumption, that more goods can be produced than can be sold for profit, and that more capital exists than can find remunerative investment. (p. 81)

As a result, Luxemburg (1972) adds, "capitalism needs ... a market for its surplus value, a source of supply for its means of production and ... a reservoir of labour power for its wage system" (pp. 368-369). Colonial expansion serves this purpose, but it is necessarily a culturally and materially destructive action as Luxemburg explains:

Capital is faced with difficulties because vast tracts of the globe's surface are in the possession of social organizations that have no desire for commodity exchange or cannot, because of the entire social structure and the forms of ownership, offer for sale the productive forces in which capital is primarily interested.... Since the primitive associations of the natives are the strongest protection for their social organizations and for their material bases for existence, capital must begin by planning for the systematic destruction and annihilation of all non-capitalist social units which obstruct its development. (pp. 370-371)

Wealthy capitalists, argues Hobson (1965), whose economic power and political influence put them "in a unique position to manipulate the policy of nations" (p. 53), pressure imperial governments to "create new public debts, float new companies, and to cause constant considerable

\footnotetext{
${ }^{1}$ They differ in their opinions on whether capitalism can be tamed through reform, or must be dismantled though revolution.
} 
fluctuations of values" (p. 53), and, finally, to generate "an enthusiasm for expansion" (p. 59). Lenin (1967), demonizing the banking industry primarily in this respect, agrees, writing that,

As long as capitalism remains what it is, surplus capital will be utilized not for the purpose of raising the standard of living of the masses in a given country, for this would mean a decline in profits for the capitalists, but for the purpose of increasing profits by exporting capital abroad to the backward countries. In these backward countries profits are usually high, for capital is scarce, the price of land is relatively low, wages are low, raw materials are cheap. (p. 724)

Thus, according to Hobson, Luxemburg, and Lenin, capitalism breeds violent colonial expansion, and this, in turn, incites cultural destruction.

\section{Gramsci}

Another important expansion on Marxian thought was introduced by Gramsci (1957). As we discussed earlier, Marx had assumed that the cultural beliefs, ideas, and moors in a society were more or less a mere reflection of the power structures in its economic base. Ideology, in this perception, served only the dominant class in the maintenance of its power. Gramsci certainly agreed that this ideological hegemony tended to serve the maintenance of existing structural inequalities, but accorded a degree of autonomy to the world of ideas vis-à-vis the economic base. Ideological dominance, according to Gramsci, was often necessary for a dominant class to maintain its power. The ideological realm could, then, become a field in which the subaltern could resist its own marginalization. Despite the immense power the "dominant class" has in "maintaining, defending and developing the theoretical or ideological 'front'," Gramsci (1985) argued, an innovative subaltern group could counteract this with its own ideological production via the creation of,

The spirit of scission, in other words the progressive acquisition of the consciousness of its own historical personality, a spirit of scission that must aim to spread itself from the protagonist class to the classes that are its potential allies—all this requires a complex ideological labour. (p. 389) 
Gramsci's formulation is important because it introduces for us the space of "civil society" - a third sector that is interwoven with the state and the economy. Ideology and culture are the same things for Gramsci; these exist in this third sector, and so do ideological or cultural resistance. Resistance in the third sector would become central to many conflictconscious concepts of development that would emerge later in the twentieth century.

\section{Sociological Approaches}

With Compte's (1856) attempt to establish the discipline of sociology as a form of "social physics," an alternative way of viewing the relationship between progress and culture became available. The early sociological approaches turned the economistic depiction of human society and economy on his head. Sociologists tended to refuse the depiction of economy as a sphere that was separable from society. They also rejected the idea that economy or society was little more than the resultant of the actions of individuals or groups which acted to satisfy their own pre-ordained interests. Ideas of progress remained deep-rooted in these arguments, but culture was given a leading role in its actualization. The most important amongst these early sociological thinkers were Emile Durkheim and Max Weber.

\section{Emile Durkbeim}

Durkheim speaks of culture in terms of the "moral" or "social" forces which actively shape each member of society. As a result, the existence of an asocial individual such as the homo economicus of neoclassical thought is considered to be a misnomer. "Our tendencies," writes Durkheim (1895/2003), "are not developed by ourselves but come to us from without" (p. 128). The set of needs, tastes, and wants that would be interpreted by economists as a stable utility function of the individual is, for Durkheim, "a group condition repeated in the individual because imposed on him. It is found in each part because it exists in the whole, rather than in the whole because it exists in the parts" (p. 130). Durkheim (1893/2000) holds that, if there is a dominant tendency in human nature, it is a predisposition to build solidarity between members of a society - a solidarity which gives form and meaning to the world. Individuals, their values, tastes, beliefs, and habits are the product of this solidarity (p. 43). 
Durkheim (1893/2000) discusses two important types of solidarity which link the idea of culture directly to the idea of progress. "Mechanical solidarity" exists in "traditional" or primitive" societies. This solidarity is based on sameness, as each member carries out more or less the same social roles as all others. As "population is continually becoming more concentrated," resulting from the "the formation and development of towns" and an increase in "the number and speed of the means of communication," a new, more intense type of solidarity becomes possible (ibid., pp. 48-49). With this newly emergent "organic solidarity," a division of labour occurs. This division does not, however, imply a diminishment of solidarity in general-rather the opposite. The division of labour, Durkheim argues, has as its main purpose a deepening of social solidarity, for it allows individuals and groups of individuals to act as separate specialized organs within a greater social organism. This organic form of solidarity, which is established most completely in modern Europe and North America, is, for Durkheim, the evolutionary end to which human societies progress. He argued that "to struggle against nature," as human density increases, "we need to possess more vigorous faculties, deploy more productive energies" (p. 38). The division of labour, therefore, becomes unavoidable as human societies progress. With all biological life forms, "an organism occupies the more exalted place in the animal hierarchy the more specialized its functions are" (p. 38). "The division of labour in society" then,

appears no more than a specialized form of this general development. In conforming to this law societies apparently yield to a movement that arose long before they existed and which sweeps in the same direction the whole of the living world. (Ibid.)

Social progress as depicted by Durkheim (1893/2000), then, is a natural evolutionary move from simple (traditional) to complex (modern) society. Spurred by demographic growth, society advances into a kind of superorganism with an increasing number of specialized organs, and deepening interdependence. Economic growth and increased industrialization result from this change, but are not the goal of it. These things are secondary effects-positive symptoms of the social need to increase solidarity. Since needs and wants, for Durkheim, are set by society, an innate drive to acquire more material goods cannot possibly drive or define social progress. This, for Durkheim, is the point on which the political economists 
tended to err. Their resultant analyses have been misconstrued as a result. The discipline of sociology must, therefore, be established as the preeminent social science in providing the policy prescriptions that will guide social progress according to Durkheim.

\section{Max Weber}

In the work of Weber, one does not find mention of a natural and inevitable historical progression from a less desirable state to a more desirable one. The word "progress," in fact, usually appears in quotation marks in his work (1919, p. 78). One does, however, find a detailed historical interpretation of the way in which modern capitalist bureaucratic society came to exist. Certainly, in The Protestant Ethic and the Spirit of Capitalism, Weber (1905) concedes that the appropriation of material means of production, free markets, mechanization, and a particular legal regime all contributed causally to the rise of capitalist society, but he holds that these were necessary, but not sufficient, conditions. Many civilizations had existed before with these traits, he argued, and yet they did not develop into modern capitalist states. The key input into the rise of capitalism, for Weber, was a particular cultural manifestation-a capitalistic spirit.

This spirit was rooted originally in religion. In the Old Testament, Weber (1905) reminds us that "wealth" in itself was considered "morally suspect" (p. 68). With the rise of Protestantism which preceded the industrial revolution, however, this association was subtly changed. With Protestantism it was believed that a man was assigned a calling by Godlabour in His service. It was believed, specifically for the Calvinists and Puritans, that individual ascendance into heaven was preordained. Success in a calling came to stand as proof of predestination. "Wealth," Weber suggested, came to be understood as "bad ethically only in so far as it is a temptation to idleness and sinful enjoyment of life, and its acquisition is bad only when it is the purpose of later living merrily without care" (p. 70). "But as a performance of duty in a calling," Weber continues, "it is not only morally permissible, but actually enjoined" (ibid.). "Favour in the sight of God" became demonstrable in "private profitableness," for if God "shows one of His elect a chance of profit, he must do it with a purpose. Hence the faithful Christian must follow the calling by taking advantage of the opportunity" (ibid.).

At the same time, however, frugality was religiously encouraged. "Protestant asceticism," Weber (1905) continued, "acted powerfully 
against the spontaneous enjoyment of possession; it restricted consumption, especially of luxuries" (p. 72). This religiously initiated frugality mixed with industriousness, Weber argues, provided the conditions for the inception of the capitalist order:

When the limitation of consumption is combined with this release of acquisitive activity, the inevitable practical result is obvious: accumulation of capital through ascetic compulsion to save. The restraints which were imposed upon the consumption of wealth naturally served to increase it by making possible the productive investment of capital. (Ibid.)

Modern rationalistic-secular capitalist society proceeded from the cultural prerequisite of Protestantism. "The Puritan outlook," Weber argued, "stood at the cradle of economic man" (ibid.). "Today the spirit of religious asceticism," he continued, "has escaped from the cage. But victorious capitalism, since it rests on mechanical foundations, needs its support no longer" (p. 73). This secular capitalism was a snare, according to Weber (1919). The human creature, usually fantastically engaged with mutable culture, became subdued by a capitalist bureaucratic system. Weber lamented that mankind had become trapped in a bureaucratic rationalized intellectualism which,

means that principally there are no mysterious incalculable forces that come into play, but rather that one can, in principle, master all things by calculation. This means that the world is disenchanted. One need no longer have recourse to magical means in order to master or implore the spirits, as did the savage, for whom such mysterious powers existed. Technical means and calculations perform the service. (p. 78)

As we will see, this sudden disappearance of culture in the magical hands of capitalist scientific modernity, although lamented by Weber, would become central to early forms of developmentalist theory in the midtwentieth century.

\section{Veblen and the Institutional Economists}

It may count to some as somewhat of a heresy to list the institutional economists here under the heading of "sociological approaches to development." Indeed, the institutionalists, from the school's founder Thorstein 
Veblen to later proponents of "old" institutionalism such as Robert Frank, were and are all trained as economists who worked/work in economics departments. It is their theoretical assumptions, however, that set them apart from orthodox economists and placed them within the realm of sociology. All economic action, for institutionalists, is conditioned, even determined, by the place of the actor within institutions. An institution, according to Commons (1931),

ranges all the way from unorganized custom to the many organized going concerns, such as the family, the corporation, the trade association, the trade union, the reserve system, the state. (p. 649)

As a result of this thinking, the institutionalists condone a shift in economic thinking. As Commons explains,

It is this shift from commodities and individuals to transactions and working rules of collective action that marks the transition from the classical and hedonic schools to the institutional schools of economic thinking. The shift is a change in the ultimate unit of economic investigation. The classic and hedonic economists, with their communistic and anarchistic offshoots, founded their theories on the relation of man to nature, but institutionalism is a relation of man to man. (p. 652)

The problem for many is that to formulate economic theories as social relations between human beings is to do sociology. It is for this reason that Talcot Parsons (1937) would denounce institutional economics as a field. In fact, most institutional economists, when pressed, have had difficulty differentiating their field from the economic sociology that was initiated by Weber and Durkheim, and vice versa. The fields remain quite insulated from one another, regardless (Velthuis, 1999). Perhaps the placement of this entry will go some small way towards the erosion of this unnecessary divide.

Culture is the fundamental institution for institutional economists. This is evident in Veblen's (1899/1994) foundational work on modern consumer society. Such a society, argued Veblen (not unlike Adam Smith), is based on emulative action in which the object of the economic actor is to demonstrate success in life through the consumption of goods and services of a quality and quantity equal to or greater than other members of the social group. Quality of such good is socially defined, or "canonized" 
as often as it is an objective feature. Human action, for Veblen, was propelled not by an insatiable set of stable wants as the neoclassical economists insisted, but by a positional game whose goal was status and belonging in a particular type of society.

The particular society that Veblen was concerned with emerged from a "predatory," competitive, "barbarian" culture, as it achieved technology that allowed for the production of goods in excess of the amount required for survival (pp. 1-6). Veblen argued that to display status, it was necessary to show the absence of a need to work in order to acquire the means of subsistence. Occupations, such as lawyer or professor, correspondingly gained prestige, and those such as farmer or factory worker lost it. In fact, the former were not so much occupations for Veblen, as shows of "conspicuous leisure" (p. 23). Similarly, the famous phrase "conspicuous consumption" was coined by Veblen in order to describe the use of goods and services with the intent of displaying their non-necessary nature (for subsistence) and, in so doing, to display one's place in a social structure (p. 43).

Development, defined as an increase in material production, is constant, yet largely unexplained in the account-its advance is accorded to technological change (which is unexplained). Because of emulative effects, however, development that has the aim to satisfy human needs through increased production has little use for Veblen. "Evidently" he argues,

a satiation of the average or general desire for wealth is out of the question.... $[\mathrm{N}] \mathrm{o}$ general increase of the community's wealth can make any approach to satiating this need, the ground of which is the desire of everyone to excel everyone else in the accumulation of goods. (p. 39)

Later, Dusenberry (1949) would argue that an egalitarian redistribution of income would quell competitive consumption, decrease waste, and increase contentment. This would reduce what he called the "demonstration effect" that caused unhappiness as one individual witnessed and wished to emulate the consumption practices of others. Later, Nurkse (1957) would relate this directly to the development of formerly colonized nations by introducing the "international demonstration effect," arguing that,

when people come into contact with superior goods or superior patterns of consumption, with new articles or new ways of meeting old wants they are 
apt to feel after a while a certain restlessness and dissatisfaction. Their knowledge is extended, their imagination stimulated; new desires are aroused. (p. 112)

Nurkse's thesis was presented as an analysis of a phenomenon he believed to be blocking capital accumulation, and therefore material production. It should be noted however that Nurkse's, Duesenberry's, and Veblen's work introduced an uncertainty in economic theory regarding the meaning of progress. This was perhaps an unavoidable result of the insistence that human wants are culturally conditioned, since it begs the question: is it more prudent to increase production to increase well-being, or to change wants? This kind of critical questioning of the use of material production was not present in Marxism, nor neoclassicalism, nor even in the sociology of Weber or Durkheim.

The institutionalist critique would lose force quickly, however. Although it was actually the most prominent school in the field of economics in the early twentieth century, institutionalism would virtually disappear until the end of that century. ${ }^{2}$ This fall from grace was likely initiated by both the rise of neoclassicalism in economics departments and by Parson's chastising of the institutionalists for overstepping the bounds of economics and wandering into the sociological realm (Velthuis 1999).

\section{Conclusion}

It was the purpose of Chaps. 2 and 3 to explore the rich intellectual traditions that underlie the post-WWII development thinking, which will be discussed in the next two chapters. Particular attention was paid to the ways in which the concepts of culture and development appeared in these traditions. This pre-WWII thought was divided into four major groups for the purpose of this exposition: classical political economy, neoclassical economics, (the topic of Chap. 2), critical political economy, and sociological approaches (the topic of the current chapter). For the classical political economists, development clearly implied an increase in material wealth, but this was a quest that was to be tempered with ethics, and the

\footnotetext{
${ }^{2}$ This is thought to generally be true as economics departments became satiated with neoclassicalism. But the very notable prevalence of institutional economists such as John Kenneth Galbraith and Robert Heilbroner, throughout the twentieth century, must be noted as exceptions to this rule.
} 
knowledge that social conflict may emerge from divergent class interests. Human behaviour was depicted as atomistic and self-interested in the economic realm, but this was realized to be an abstraction from the cultural situation of human values, and this cultural situation was actively explored by the classical political economists themselves.

The marginal revolution, Marx's critique, and the inception of the science of sociology emerged at approximately the same time. This may be viewed as the splitting of the older holistic study of political economy into three different traditions. To the neoclassical economists went the classical political economist's appreciation for the market and the tendency to sever economic action from culture and ethics. To the Marxists went the labour theory of value and the social conflict that was implied. To the sociologists went the larger questions of the ways in which social interaction and cultural situation formed human values and economic action. All inherited the concept that human societies progress as they gain material wealth through technological innovation (although this was qualified substantially by the institutionalists). Not to do so was, for all, to be stuck in a "barbarian," "primal," or "traditional" form of existence. In this form of society, it was assumed humans were subject to the whims of nature instead of dominating it to their own ends. Such a life had been described to all of these thinkers by one of their most notable intellectual forbearers, Thomas Hobbes (1651), as being "nasty, brutish and short" (p. 52). There is little wonder, then, that each if the theorists discussed in Chaps. 2 and 3 tacitly or explicitly defined progress as any movement away from this condition. As we will see in the next chapter, this definition will be refined substantially by the post-WWII development theorists.

\section{REFERENCES}

Commons, J. R. (1931). Institutional Economics. American Economic Review, $21,648-657$.

Compte, A. (1856). Cours de Philosophie Positive. London: Bell.

Deane, P. (1978). Evolution of Economic Ideas. London and New York: Cambridge University Press.

Durkheim, E. (1893/2000). "Sociological Method" from The Rules of Sociological Method. In G. Bailey \& N. Gayle (Eds.), Social Theory: Essential Readings. New York: Oxford. 
Durkheim, E. (1895/2003). The Division of Labour in Society. In J. T. Roberts \& A. Hite (Eds.), From Modernization to Globalization: Perspectives on Development and Social Change. Malden, MA: Blackwell.

Dusenberry, J. S. (1949). Income, Saving and the Theory of Consumer Behavior. Cambridge, MA: Harvard University Press.

Eagleton, T. (1991). Ideology: An Introduction. London: Verso.

Gramsci, A. (1957/1971). Selections from the Prison Notebooks. New York: International Publishers.

Gramsci, A. (1985). Selections from the Cultural Writings(D. Forgacs \& G. Nowell, Eds.). London: Lawrence and Wishart.

Heilbroner, R. (1999). Teachings from the Worldly Philosophy. New York and London: W.W. Norton and Company.

Hobbes, T. (1651). Leviathan. Glasgow 1974.

Hobson, J. A. (1965). Imperialism: A Study (Vol. 103). University of Michigan Press.

Hunt, E. K. (2002). History of Economic Thought: A Critical Perspective. New York: ME Sharpe.

Lenin, V. I. (1967). Lenin on the National and Colonial Questions: Three Articles. Foreign Languages Press.

Luxemburg, R. (1972). The Accumulation of Capital: An Anti-critique. Imperialism and the Accumulation of Capital. Monthly Review Press.

Marx, K. (1846/1968). The German Ideology. Delhi: Progress Publishers.

Marx, K. (1867/1961). Capital (Vol. 1). Moscow: Foreign Languages.

Marx, K. (2001). The German Ideology Part One, with Selections from Parts Two and Three, Together with Marx's "Introduction to a Critique of Political Economy”. New York: International Publishers.

Marx, K., \& Engels, F. (1848/1965). The Communist Manifesto. In A. P. Mendel (Ed.), Essential Works of Marxism. New York: Bantam.

Nurkse, R. (1957). Problems of Capital Formation in Underdeveloped Countries. Oxford: Blackwell.

Parsons, T. (1937). The Structure of Social Action. New York: McGraw-Hill.

Veblen, T. (1899/1994). The Theory of the Leisure Class. New York: Dover Publications.

Velthuis, O. (1999). The Changing Relationship Between Economic Sociology and Institutional Economics. American Journal of Economics and Sociology, $58(4), 629-649$.

Weber, M. (1905/2000). The Protestant Ethic and the Spirit of Capitalism. In J. Roberts \& A. Hite (Eds.), From Modernization to Globalization: Perspectives on Development and Social Change. Oxford: Blackwell.

Weber, M. (1919/2000). Science as a Vocation. In R. Roberts \& A. Hite (Eds.), From Modernization to Globalization: Perspectives on Development and Social Change. Oxford: Blackwell. 
Open Access This chapter is licensed under the terms of the Creative Commons Attribution 4.0 International License (http://creativecommons.org/licenses/ by $/ 4.0 /$ ), which permits use, sharing, adaptation, distribution and reproduction in any medium or format, as long as you give appropriate credit to the original author(s) and the source, provide a link to the Creative Commons licence and indicate if changes were made.

The images or other third party material in this chapter are included in the chapter's Creative Commons licence, unless indicated otherwise in a credit line to the material. If material is not included in the chapter's Creative Commons licence and your intended use is not permitted by statutory regulation or exceeds the permitted use, you will need to obtain permission directly from the copyright holder. 